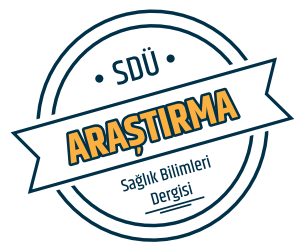

Sdü Sağlık Bilimleri Dergisi / Cilt 10 Sayı 2 / 2019

\title{
Hemşirelik Öğrencilerinin Kanıta Dayalı Hemşireliğe İlişkin Tutum ve Davranışlarının Belirlenmesi
}

\section{Determination of Evidence-Based Nursing Attitudes and Behaviors of Nursing Students}

Hasan Evcimen ${ }^{1}$, Neşe İşcan Ayyıldız ${ }^{1}$

${ }^{1}$ Trabzon Üniversitesi, Tonya Meslek Yüksekokulu, Sağlık Bakım Hizm. Böl., Evde Hasta Bakımı AD, Trabzon, Türkiye.

\section{Özet}

Amaç: Bu araştırma hemşirelik son sınıf öğrencilerinin kanıta dayalı hemşireliğe yönelik bilgi ve tutumlarını belirlemek amacıyla yapılmıştır.

Materyal-Metot: Tanımlayıcı tipte olan bu araştırma bir üniversitenin hemşirelik bölümünün son sinıfinda okuyan 143 öğrenci ile yürütülmüştür. Verilerin toplanmasında öğrenci bilgi formu ve kanıta dayalı hemşireliğe yönelik tutum ölçeği kullanılmıştır. Verilerin değerlendirilmesinde yüzdeleme, frekans, $\mathrm{t}$ testi kullanılmıştır.

Bulgular: Araştırmaya katılanların yaş ortalaması $22,01 \pm 0,95$ tir. Öğrencilerin genel ağırlıklı not ortalamaları ise $76,62 \pm 7,85^{\prime}$ 'dir. Araştırmaya katılan öğrencilerin $\% 80,4$ 'ü kadın, \%72,7'si alana özgü dergi/yayın takip etmediğini \%69,2'sinin lisansüstü eğitim yapmayı düşündüğü görülmüştür. Kanıta dayalı hemşireliğe yönelik tutum ölçeği toplam ortalama puanı $61,65 \pm 9,30$ ' dır.

Sonuç: Öğrencilerin kanıta dayalı hemşireliğe yönelik tutum ve niyetlerinin iyi düzeyde olduğu görülmektedir. Kadın öğrencilerin erkeklere göre ölçek toplam puanı ve alt boyutlarında daha yüksek puan aldığı görülmektedir $(p<0,05)$. Lisansüstü eğitim düşünenlerin düşünmeyenlere göre ölçek toplam ve alt boyut puanlarının daha yüksek olduğu gözlemlenmiştir $(\mathrm{p}<0,05)$.

Anahtar kelimeler: Hemşirelik, Kanıta Dayalı Hemşirelik, Öğrenci, Tutum.

\begin{abstract}
Objective: This research was conducted to determine the knowledge and attitudes of nursing senior students towards evidence-based nursing.
\end{abstract}

Material-Method: This descriptive research was conducted with 143 students studying in the final year of a university's nursing department. The student information form and Attitude Towards Evidence-Based Nursing Questionnaire were used in the data collection.Percentage, frequency, $t$ test were used in the evaluation of the data.

Results: The mean age of the participants was $22.01 \pm 0.95$. The average weighted average of the students is $76.62 \pm 7.85$. It was seen that $80.4 \%$ of the students who participated in the research were female, $72.7 \%$ did not follow the field specific journal / publication, and $69.2 \%$ thought to do post-graduate education. The mean score of theAttitude Towards EvidenceBased Nursing Questionnaire is 61.65 \pm 9.30 and the cronbach alpha coefficient of the scale is 0.92 .

Conclusions: It is seen that students' attitudes and intentions towards evidence-based nursing are at a good level.It is seen that female students score higher on the scale total points and sub dimensions of male students $(\mathrm{p}<0.05)$. It was observed that scale total and subscale scores were higher than those who did not think of graduate education $(\mathrm{p}<0.05)$.

Keywords: Nursing, Student, Evidence-Based Nursing, Attitudes.

\section{Giriş}

Toplumlarda artan yaşlı nüfusla birlikte sağlık hizmetlerine olan harcamalar ve bakım yükü artış göstermiştir. Kısıtlı kaynakların etkin kullanımı ve verilen sağ lık bakım hizmetlerinin kalitesindeki artış kanıta dayalı uygulamalara bağlıdır. Bakımda kalitenin oluşmasında kanıt temelli uygulamalar esastır (1). Epidemiyolog Dr. Archie Cochrane tarafindan 1972 yilında ortaya atılan kanıta dayalı uygulamalar önerisi ilkin tıp alanında kendini göstermiştir. Ardından bu kavram kanıta dayalı uygulama adıyla hemşirelikte olduğu gibi diğer geniş kitlelerce de ifade edilmeye başlanmıştır (2).

Hemşirelik alanında ise kanıta dayalı hemşirelik, hastaların bakımlarına yönelik kararlar alırken bilime dayalı bir şekilde oluşan en iyi kanıtın hastaların tercihlerinin de göz önüne alınarak sentezlenmesi sonucu ortaya çıkan en iyi bakımın uygulanması sürecidir (3). Kanıta dayalı hemşireliğin altındaki en temel kavram, verilen bakım hizmetinin geleneksel ya da sezgisel deneyimler yerine yüksek etkiye sahip kanıtlar ışığında verilmesidir $(4,5)$. Artan sağlık bakım maliyetlerinin yanında verilen bakım hizmetinin kaliteli ve maliyet etkin istenmesi kanıta dayalı uygulamaları kaçınılmaz kılmaktadır. Hemşireler tarafından verilen bakım hizmetlerinin kanıt temelli olması, bakımda kalite ve olumlu yönde fark oluşturacağı için hasta memnuniyetinde de artış sağlanacaktır.

Dünyada ABD, Kanada, İngiltere ve Hollanda gibi birçok ülkede kanıta dayalı eğitim merkezleri açılmış ve hemşirelik eğitiminin bilimsel kanıt çerçevesinde gelișmesinin önemi belirtilmiştir. Dünya Sağlık Asamblesi'nin 2001 yılında gerçekleştirmiş olduğu 
toplantıda ebelik ve hemşirelik hizmetlerinin kanıt temelli olması gerektiği ve konuyla ilgili alt yapının sağlanması gerekliliğini bildirmiştir. Uluslararası Hemşirelik Birliği (International Council of Nursing=ICN) tarafindan tüm hemşirelere uygulamalarının kanıt temelli olması konusunda yapmış olduğu vurgu, konunun önemini ortaya koymaktadır (6). Türkiye'de 2010 yılında yayımlanan hemşirelik yönetmeliğindeki hemşirenin görev yetki ve sorumlulukları arasında hemşirelik bakımını kanıta dayalı bir şekilde planlayıp uygulaması ve yine sonuçlarını buna göre değerlendirmesi gerektiği belirtilmektedir (7). Yükseköğretim kurumlarının Bologna süreci uygulamaları kapsamında lisans ve lisansüstü eğitim programları mezunlarının kanıt kullanma yeteneklerinin gelişiminin önemi belirtilmiştir (8). Değişik ülkelerde kanıta dayalı uygulamalara ilişkin hemşirelik öğrencilerinin bilgi, tutum ve farkındalıklarını belirleyen araştırmalar yapılmıştır (9-11). Türkiye'de konuyla ilgili yapılan çalışmalar ise oldukça sınırlıdır $(6,12,13)$. Cruz (2016) kanıta dayalı hemşirelikle ilgili 188 hemşirelik öğrencisiyle yapmış olduğu çalışmasında öğrencilerin konuya ilişkin yüksek bir farkındalığa sahip oldukları ve katılmış oldukları kanıta dayalı hemşirelikle ilgili kursun beceri ve tutumlarını pozitif yönde gelişim sağlandığı görülmüştür (9).

$\mathrm{Bu}$ çalışma hemşirelik bölümü son sınıfinda okuyan öğrencilerin kanıta dayalı hemşireliğe ilişkin tutum, davranış ve farkındalıklarını incelemek amacıyla tanımlayıcı olarak planlanmıştır.

\section{Materyal-Metot}

$\mathrm{Bu}$ çalışma tanımlayıcı kesitsel tipte planlanmıştır. Çalışmanın evrenini Karadeniz Teknik Üniversitesi Üniversitesi Sağlık Bilimleri Fakültesi Hemşirelik Bölümü'ndeki son sınıf öğrencilerinin tamamı oluşturmuştur. Örneklem seçimine gidilmemiş olup evrenin tamamına ulaşılması amaçlanmıştır. 202 öğrenciden araştırmanın yapıldığı dönem okulda olmayan, araştırmaya katılmak istemeyen ve anketi eksik dolduranlar çalışmaya dahil edilmemiş ve $143(\% 73,8)$ öğrenci ile çalışma yürütülmüştür.

Verilerin toplanmasında araştırmacılar tarafından hazırlanan öğrenci bilgi formunun yanı sıra Kanıta Dayalı Hemşireliğe Yönelik Tutum Ölçeği (KDHYTÖ) kullanılmıştır. Öğrenci bilgi formunda yaş, cinsiyet, genel ağırlıklı not ortalaması (GANO), kanıta dayalı hemşirelik, araştırma ve literatür tarama bilgilerini belirlemeye yönelik sorular yer almaktadır. KDHYTÖ ise Ruzaffa-Martinez ve ark.(2011) tarafindan geliştirilmiş olup Türkçe geçerlilik ve güvenilirlik çalışması Ayhan(2013) tarafindan yapılmıştır (14). Ölçek toplam 15 soru ve üç alt boyuttan oluşmaktadır. Bu alt boyutlar; "kanıta dayalı hemşireliğe yönelik inanç ve beklentiler alt boyutu", "kanıta dayalı uygulama niyeti alt boyutu" ve "kanıta dayalı hemşirelik ile ilgili duygular alt boyutu" şeklindedir. Ölçekten minimum 15 maksimum 75 puan alınabilmektedir. Alınan puanın yüksek olması kanıta dayalı hemşireliğe ilişkin tutumunda iyi olduğunu göstermektedir. Likert 5'li tipte hazırlanan ölçekte 7 olumsuz, 8 olumlu madde yer almaktadır. Ölçeğin ve alt boyutlarının madde sayıları ve cronbach $\alpha$ katsayıları verilmiştir (Tablo 1).

Araştırma öncesi ölçeğin Türkçe geçerlilik ve güvenilirlik çalışmasını yapan yazardan yazılı izin alınmıştır. Karadeniz Teknik Üniversitesi Tıp Fakültesi Bilimsel Araştırmalar
Etik Kurulu'ndan 2018/93 sayılı kararla onay alınmış olup katılımcılardan da bilgilendirilmiş gönüllü onam formu alınmıştır. Anketler yüz yüze görüşme tekniği ile toplanmıştır. Her bir anket formunun doldurulması yaklaşık 8-10 dakika sürmüştür.

Verilerin değerlendirilmesinde sayı, yüzdeleme, frekans, ortalama ve t testi kullanılmıştır. Veriler $\% 95$ güven aralığında ve $\mathrm{p}<0,05$ olarak anlamlandırılmıştır.

\section{Bulgular}

Araştırmaya 143 hemşirelik son sınıf öğrencisi katılmış olup \%73,8'lik katılım sağlanmıştır. Araştırmaya katılan öğrencilerin yaş ortalaması 22,01 $\pm 0,95$ dir. Araştırmaya katılan öğrencilerin GANO ortalamaları ise 76,62 \pm , $85^{\prime}$ dir. Katılımcıların \%80,4’i (n:115) kadındır. Çalışmaya katılan öğrencilerin \%72,7’ü (n:104) alana özgü dergi/yayın takip etmediği, \%69,2’u (n:99) lisansüstü eğitim yapmak istediğini belirtmiştir. Katılımcıların \%72'ü (n:103) hemşirelikle ilgili kongre / sempozyuma katıldığını, \%77,6’i (n:111) kanıta dayalı hemşirelik kavramını daha önce duyduğunu belirtirken \%72,7’ü (n:104) herhangi bir araştırmanın içinde yer almadığını belirtmiştir. Aynı zamanda katılımcıların hiçbiri kanıta dayalı hemşirelikle ilgili eğitim almadıklarını belirtmişlerdir. Araştırmaya katılan öğrencilerin \%69,9'ü (n:100) daha önceden literatür taraması yapmadığı görülmektedir. Literatür taraması yapanların \%79,06'ü (n:34) Google Scholar veri tabanını kullanmaktadır (Tablo 4). KDHYTÖ toplam puan ortalamas $161,65 \pm 9,30$ olup kanıta dayalı hemşireliğe yönelik inanç ve beklentiler alt boyutu puan ortalamas1 $27,86 \pm 5,81$ kanita dayalı uygulama niyeti alt boyutu puan ortalaması $16,56 \pm 2,16$ iken kanita dayal hemşirelikle ile ilgili duygular alt boyutu puan ortalaması 17,32 $\pm 2,20$ 'dir (Tablo 2). Katılımcıların aldıkları puanlara bakıldığında kanıta dayalı hemşireliğe yönelik tutumlarının iyi düzeyde olduğu görülmektedir.

Tablo 1. KDHYTÖ ve alt boyutlarının madde sayıları ve cronbach $\alpha$ katsayıları

\begin{tabular}{lcc}
\hline Alt boyutlar & $\begin{array}{c}\text { Madde } \\
\text { sayıları }\end{array}$ & $\begin{array}{c}\text { Cronbach } \\
\boldsymbol{\alpha}\end{array}$ \\
\hline $\begin{array}{l}\text { Kanıta dayalı hemşireliğe yönelik } \\
\text { inanç ve beklentiler alt boyutu } \\
(1,2,7,9,11,13,14)\end{array}$ & 7 & 0,91 \\
\hline $\begin{array}{l}\text { Kanıta dayalı uygulama niyeti alt } \\
\text { boyutu }(3,5,6,12)\end{array}$ & 4 & 0,61 \\
\hline $\begin{array}{l}\text { Kanıta dayalı hemşirelik ile ilgili } \\
\text { duygular alt boyutu (4, 8, 10, 15) }\end{array}$ & 4 & 0,80 \\
\hline $\begin{array}{l}\text { Kanıta dayalı hemşireliğe yönelik } \\
\text { tutum ölçeği (1-15 arası) }\end{array}$ & 15 & 0,92 \\
\hline
\end{tabular}

Tablo 2. KDHYTÖ ve alt boyutları ölçek toplam ortalama puanları

\begin{tabular}{lc}
\hline Ölçek ve alt boyutlar & Ort \pm s.s \\
\hline $\begin{array}{l}\text { Kanıta dayalı hemşireliğe yönelik } \\
\text { inanç ve beklentiler alt boyutu }\end{array}$ & $27,86 \pm 5,81$ \\
\hline $\begin{array}{l}\text { Kanıta dayalı uygulama niyeti alt } \\
\text { boyutu }\end{array}$ & $16,56 \pm 2,16$ \\
\hline $\begin{array}{l}\text { Kanıta dayalı hemşirelik ile ilgili } \\
\text { duygular alt boyutu }\end{array}$ & $17,32 \pm 2,20$ \\
\hline KDHYTÖ toplam puan & $61,65 \pm 9,30$ \\
\hline
\end{tabular}


Kadın hemşirelik öğrencilerinin erkeklere göre ölçek toplam puanı ve alt boyut puanlarında daha yüksek puan aldıkları gözlemlenmiş olup kanıta dayalı hemşireliğe yönelik tutumlarının erkeklere göre daha iyi olduğu gözlemlenmiştir $(p<0,05)$. Lisansüstü eğitim yapma düşüncesi olan öğrencilerin yapmak istemeyen öğrencilere göre ölçek toplam puanında ve alt boyutlarında daha yüksek puan aldıkları görülmüş bunun da anlamlı bir farklılık oluşturduğu saptanmıștır $(p<0,05)$. Kongre / sempozyuma katılan öğrencilerin katılmayanlara göre kanıta dayalı hemşireliğe yönelik tutumlarının daha iyi olduğu ve bunun da istatistiksel olarak anlamlı farklılık oluşturduğu gözlemlenmiştir $(\mathrm{p}<0,05)$ (Tablo 3.)

Tablo 3. Katılımcıların tanıtıcı özelliklerine göre alt boyut ve KDHYTÖ puan ortalamaları

\begin{tabular}{|c|c|c|c|c|c|c|}
\hline Değișkenler & $\mathbf{n}$ & $\%$ & $\begin{array}{c}\text { Kanıta dayalı } \\
\text { hemşireliğe yönelik } \\
\text { inanç ve beklentiler } \\
\text { alt boyutu } \\
(\mathrm{X} \pm \mathrm{S} . \mathrm{S})\end{array}$ & $\begin{array}{c}\text { Kanita dayalı } \\
\text { uygulama } \\
\text { niyeti alt } \\
\text { boyutu } \\
(\mathrm{X} \pm \mathrm{S} . \mathrm{S})\end{array}$ & $\begin{array}{l}\text { Kanıta dayalı } \\
\text { hemşirelik ile } \\
\text { ilgili duygular } \\
\text { alt boyutu } \\
\text { (X } \pm \text { S.S })\end{array}$ & $\begin{array}{c}\text { KDHYTÖ } \\
\text { toplam puanı } \\
(\mathrm{X} \pm \mathrm{S} . \mathrm{S})\end{array}$ \\
\hline \multicolumn{7}{|l|}{ Cinsiyet } \\
\hline Erkek & 28 & 19,6 & $22,68 \pm 5,67$ & $14,56 \pm 1,96$ & $15,64 \pm 1,44$ & $52,8 \pm 8,40$ \\
\hline Kadın & 115 & 80,4 & $29,12 \pm 5,11$ & $17,04 \pm 1,88$ & $17,72 \pm 2,16$ & $66,45 \pm 8,25$ \\
\hline $\mathrm{P}$ & & & $\mathbf{0 , 0 1}$ & $\mathbf{0 , 0 1}$ & $\mathbf{0 , 0 1}$ & 0,01 \\
\hline $\mathrm{T}$ & & & $-5,803$ & $-6,103$ & $-4,828$ & $-6,267$ \\
\hline \multicolumn{7}{|c|}{ Yayın / Dergi takip etme durumlarına göre } \\
\hline Evet & 39 & 27,3 & $29,26 \pm 5,88$ & $16,76 \pm 1,68$ & $17,20 \pm 2,24$ & $63,3 \pm 9,15$ \\
\hline Hayır & 104 & 72,7 & $27,3 \pm 5,67$ & $16,48 \pm 2,28$ & $17,36 \pm 2,20$ & $61,2 \pm 9,3$ \\
\hline $\mathrm{P}$ & & & 0,07 & 0,44 & 0,74 & 0,22 \\
\hline $\mathrm{t}$ & & & 1,796 & 0,773 & $-0,322$ & 1,210 \\
\hline \multicolumn{7}{|c|}{ Lisansüstü eğitim düşünme durumuna göre } \\
\hline Evet & 99 & 69,2 & $29,61 \pm 4.90$ & $17,20 \pm 1.80$ & $17,72 \pm 2,24$ & $64,50 \pm 8,10$ \\
\hline Hayır & 44 & 30,8 & $23,94 \pm 5.81$ & $15,12 \pm 2.16$ & $16,36 \pm 1,76$ & $55,50 \pm 9,00$ \\
\hline $\mathrm{P}$ & & & $\mathbf{0 , 0 1}$ & 0,01 & $\mathbf{0 , 0 2}$ & $\mathbf{0 , 0 1}$ \\
\hline $\mathrm{t}$ & & & 5,914 & 5,863 & 3,523 & 5,915 \\
\hline \multicolumn{7}{|c|}{ Araştırmaya katılma durumuna göre } \\
\hline Evet & 39 & 27,3 & $29,82 \pm 4,83$ & $17,24 \pm 1,64$ & $17,52 \pm 2,16$ & $64,65 \pm 7,65$ \\
\hline Hayır & 104 & 72,7 & $27,09 \pm 6,02$ & $16,28 \pm 2,24$ & $17,24 \pm 2,20$ & $60,60 \pm 9,60$ \\
\hline $\mathrm{P}$ & & & $\mathbf{0 , 0 1}$ & $\mathbf{0 , 0 1}$ & 0,49 & $\mathbf{0 , 0 2}$ \\
\hline $\mathrm{t}$ & & & 2,537 & 2,376 & 0,692 & 2,281 \\
\hline \multicolumn{7}{|c|}{ Kongre / sempozyuma katılma durumuna göre } \\
\hline Evet & 103 & 72 & $29,68 \pm 4,27$ & $17,12 \pm 1,84$ & $17,88 \pm 2,00$ & $64,65 \pm 7,05$ \\
\hline Hayır & 40 & 28 & $23,17 \pm 6,65$ & $15,08 \pm 2,20$ & $15,80 \pm 1,96$ & $54,00 \pm 10,05$ \\
\hline $\mathrm{P}$ & & & $\mathbf{0 , 0 1}$ & $\mathbf{0 , 0 1}$ & $\mathbf{0 , 0 1}$ & $\mathbf{0 , 0 1}$ \\
\hline $\mathrm{t}$ & & & 6,901 & 5,565 & 5,564 & 7,037 \\
\hline \multicolumn{7}{|l|}{ GANO } \\
\hline$<75$ & 58 & 40,6 & $25,13 \pm 6,16$ & $15,60 \pm 2,40$ & $16,60 \pm 2,12$ & $57,30 \pm 9,90$ \\
\hline$\geq 75$ & 85 & 59,4 & $29,75 \pm 4,76$ & $17,20 \pm 1,68$ & $17,80 \pm 2,12$ & $64,65 \pm 7,65$ \\
\hline $\mathrm{P}$ & & & 0,01 & $\mathbf{0 , 0 1}$ & $\mathbf{0 , 0 1}$ & $\mathbf{0 , 0 1}$ \\
\hline $\mathrm{t}$ & & & $-5,146$ & $-4,801$ & $-3,556$ & $-5,196$ \\
\hline
\end{tabular}


Tablo 4. Öğrencilerin veritabanlarınıkullanma durumları

\begin{tabular}{lcc}
\hline Veri tabanları & $\mathbf{n : ( 4 3 )}$ & $\mathbf{\%}$ \\
\hline Google Scholar & 34 & 79,06 \\
Ulakbim & 6 & 13,95 \\
Medline & 3 & 6,98 \\
\hline
\end{tabular}

\section{Tartışma}

$\mathrm{Bu}$ çalışmada hemşirelik öğrencilerinin kanıta dayalı hemşireliğe yönelik olan tutum ve davranışlarının belirlenmesi amaçlanmıștır. Çalıșmaya katılan hemşirelik öğrencilerinin KDHYTÖ puan ortalamasının yüksek olduğu $(61,65 \pm 9,30)$ saptanmıştır. Aynı zamanda kanıta dayalı hemşireliğe olan tutum ve niyetin olumlu olduğu görülmektedir. Yapılan bir diğer çalışmaya bakıldığında Küçükoğlu ve ark. (2017) çalışmasında hemşirelerin kanıta dayalı hemşireliğe yönelik tutumlarının orta düzeyde olduğu belirlenmiştir (15). Adams (2009) 247 hemşirelik öğrencisiyle ile yapmış olduğu çalışmada olduğu gibi öğrencilerin kanıta dayalı hemşireliğe ilişkin olumlu tutum ve niyetleri olduğu gözlemlenmiştir (10). Cruz ve ark. (2016) 188 hemşirelik öğrencisi ile yapmış olduğu çalışmasında öğrencilerin kanıta dayalı hemşireliğe ilişkin yüksek bir farkındalık düzeyine sahip olduğunu ve bu konu ile ilgili kursa katılmış olmanın kanıta dayalı hemşireliğe yönelik tutumlarını pozitif yönde etki ettiği gözlemlenmiştir. Yine Cruz ve ark. (2016) aynı çalışmasında öğrencilerin \%60'1 kanıta dayalı hemşirelikle ilgili kursa katılmışlardır (9). Leach ve ark.(2015) yapmış oldukları çalışmada kanıt temelli uygulama eğitimlerinin hemşirelik öğrencilerinin kanıta dayalı uygulama bilgi ve becerilerini geliştireceğini ve araştırma sonuçlarını kullanmadaki engelleri azaltacağını belirtmiştir (16). Bu bağlamda ülkemizde bu konuda açılacak kurs programlarının düzenlenmesi ile birlikte kanıta dayalı hemşireliğe olan ilginin daha üst seviyelere çıkacağı ve bakım kalitesinin istendik düzeylere çıkarılmasında katkı sağlanacağı düşünülmektedir. Cruz ve ark.(2016) ve Adams (2009) çalışmalarının ikisine bakıldığında çalışmamızla benzer sonuçlar taşıdı̆̆ı görülmekte olup, hemşirelik öğrencilerinin kanıta dayalı hemşireliği önemsediği ve olumlu baktığ1 görülmektedir. Lisans eğitimi esnasında konuya ilişkin kurs programlarına katılımla birlikte mezuniyet sonrası öğrencilerin konuya daha fazla ilgi göstereceği ön görülmektedir.

Çalışmamızda hemşirelik öğrencilerinin kanıta dayalı hemşireliğe yönelik uygulama niyeti alt boyutu puanı $(16,56 \pm 2,16)$ yüksek düzeyde bulunmuştur. Dikmen ve ark. (2018) ve Merih ve ark.(2017) yapmış oldukları çalışmalarında hemşirelerin kanıta dayalı uygulama niyetlerinin orta seviyede olduğu saptanmıştır $(17,18)$. Çalışmamıza katılan hemşirelik öğrencilerinin kanıta dayalı hemşireliğe yönelik duygular alt boyutu puanı $(17,32 \pm 2,20)$ yüksek düzeyde olduğu saptanmıştır. Durmuş ve ark. (2017) sağlık çalışanları ile yapmış olduğu çalışmasında kanıta dayalı uygulamaya yönelik duygularının orta düzeyde olduğu, Yılmaz ve ark. (2018) ise kliniklerde çalışan hemşirelerin kanıta dayalı hemşireliğe yönelik duygularının düşük düzeyde olduğu bildirilmiştir $(19,20)$. Çalışmamıza katılan öğrencilerin kanıta dayalı hemşireliğe yönelik inanç ve beklentiler alt boyutu puanının $(27,86 \pm 5,81)$ yüksek düzeyde olduğu görülmüştür. Sağlık çalışanları ile yapılan çalışmalarda Yılmaz ve ark. (2018) araştırmasında kanıta dayalı hemşireliğe yönelik inanç ve beklentilerinin orta düzeyin üstünde olduğunu, Durmuş ve ark. (2017) ise çalışmasında kanıta dayalı hemşireliğe yönelik inanç ve beklentilerinin orta düzeyin altında olduğunu saptamiştır $(20,19)$.

Araştırmada kız öğrencilerin kanıta dayalı hemşireliğe yönelik puan ortalamalarının erkek öğrencilere yüksek olduğu saptanmıştır $(p<0,05)$. İnanç ve beklentiler, uygulama niyeti ve duygular alt boyutu puanlarının da erkek öğrencilere göre kanıta dayalı hemşireliğe yönelik puanlarının daha yüksek olduğu görülmüştür $(\mathrm{p}<0,05)$. Karaahmetoğlu ve ark.( 2018) yapmış oldukları çalışmada kız öğrencilerin kanıta dayalı hemşireliğe yönelik tutumlarının, inanç-beklentiler, uygulama niyeti ve duygular alt boyutları ölçek puanlarının erkeklere göre daha yüksek olduğu belirtilmiştir (21). Kurt ve ark. (2011) ise çalışmalarında kız öğrencilerin erkek öğrencilere göre not ortalamalarının yüksek olduğu ve araştırmaya olan görüşlerinin daha pozitif olduğunu belirtmiştir (22). Bu sonuçlar bağlamında kız öğrencilerin araştırma, geliştirme faaliyetlerindeki merak, istek ve niyetlerinin erkeklere göre üst düzeyde olduğunu söylemek mümkündür. Kanıta dayalı uygulamaların hemşirelikte klinik bakım sürecine entegre edilmesinde ve bakım kalitesinin arttırılmasında özellikle hemşirelik öğrencilerinin bu özelliklere sahip olması gerekliliği düşünülmektedir.

Çalışmaya katılan öğrencilerin \%72,7'sinin bilimsel dergi / yayın takip etmedikleri gözlemlenmiştir. Karadaş ve ark.(2015) yapmış oldukları çalışmada da katılımcıların \%78,4'ünün bilimsel dergi/yayın takip etmedikleri görülmüştür (12). Bilimsel dergi/yayın takip etme durumu ile kanıta dayalı hemşireliğe yönelik tutumları ve alt boyutlarında anlamlı bir farklılık saptanmamıştır. Çalışmanın örnekleminin özelliğinden kaynaklı bir sonuç olduğu düşünülmektedir. Karaahmetoğlu ve ark.(2018)'e göre makale okuyanların okumayanlara göre kanıta dayalı hemşireliği uygulama niyeti alt boyutunda anlamlı bir farklılık olduğunu belirtmiştir (21). Arslan ve ark.(2018) yapmış oldukları çalışmada hemşirelik alanıyla ilgili bilimsel yayın/dergi takip edenlerin kanıta dayalı hemşireliğe yönelik puanlarının daha yüksek olduğu saptanmıştır (23). Hemşireliğin istendik düzeylere gelebilmesi bilimsel faaliyetlere bağlıdır. Mesleki uygulamalar ve mesleki gelişmelerin yakından takibi ve kanıt temelli uygulamaların içselleştirilmesi için hemşirelik öğrencilerinin makale okumaları gerekmekte olup bu konuda desteklenmeli ve teşvik edilmelidirler.

Kongre / sempozyuma katılma durumuna göre katılanların katılmayanlara göre kanıta dayalı hemşireliğe yönelik tutum toplam puanı ve alt boyut puanları daha yüksek olup anlamlı bir farklılık oluşturmuştur $(\mathrm{p}<0,05)$. Karadaş ve ark. (2015) ise çalışmasında bilimsel etkinliklere katılım sağlayan öğrencilerin araştırmaya yönelik ilgi ve tutumlarının yüksek düzeyde olduğu bildirilmektedir (12). Arslan ve ark. (2018) yapmış oldukları çalışmada bilimsel etkinliklere katılan hemşirelik öğrencilerinin kanıta dayalı hemşireliğe yönelik puanlarının katılmayanlara göre daha yüksek olduğu 
gözlemlenmiştir (23). Karaahmetoğlu ve ark. (2018) yapmış oldukları çalıșmada bilimsel etkinliğe katılımın kanıta dayalı hemşireliğe yönelik tutum üzerinde anlamlı bir farklılık oluşturmadığını bildirmektedir (21). Hemşirelik mesleği ile ilgili bilimsel etkinliklere katılımın kanıta dayalı hemşirelik becerilerini güçlendireceğini aynı zamanda hemşireleri bilimsel araştırmaya teşvik edeceği düşünülmektedir. Bu bağlamda profesyonel ve kaliteli bir bakım hizmetinin kanıt temelli uygulamalara dayandırılmasında ve mesleki güncel uygulamaların takip edilmesinde bilimsel kongre / sempozyumlara katılım sağlanması önem taşımaktadır.

Çalışmaya katılan hemşirelik öğrencilerinin \%69,2'si lisansüstü eğitim yapmayı düşündüğünü belirtmiştir. Lisansüstü eğitim yapmayı düşünenlerin kanıta dayalı hemşirelik puanlarının düşünmeyenlere göre daha yüksek olduğu ve anlamlı bir farklılık oluşturduğu görülmektedir $(\mathrm{p}<0,05)$. Mehdrad ve ark. (2012) yapmış oldukları çalışmada yüksek eğitim düzeyine sahip hemşirelerin klinik uygulamalarda kanıt kullanımına yönelik olumlu tutum geliştirdiklerini belirtmiştir (24). Hemşirelik öğrencilerinin lisans mezuniyeti sonraları lisansüstü eğitim yapmaları ile birlikte bilimsel araştırma yapma isteklerinin pozitif yönde değişeceği ve bakım süreçlerine araştırma sonuçlarını da katıp kanıta dayalı hemşireliği içselleştirecekleri düşünülmektedir. Araştırmaya katılan hemşirelik öğrencilerinin \%27,3'ü daha önce bir bilimsel çalışmaya katıldıkları görülmüştür. Önceden bilimsel çalışmaya katılanların katılmayanlara göre kanıta dayalı hemşirelik puanlarının daha yüksek olduğu ve anlamlı farklılık oluşturduğu görülmüştür $(\mathrm{p}<0,05)$. Arslan ve ark. (2018) yapmış oldukları çalışmada hemşirelik öğrencilerinden bilimsel çalışmaya katılanların kanıta dayalı hemşireliğe yönelik tutumlarını olumlu yönde olduğu bildirilmiştir (23). Ryan (2016) çalışmasında lisans düzeyindeki hemşirelik öğrencilerinin yeterli anlamda destek verilmesi ve teşvik edilmeleri ile birlikte kanıt temelli uygulamalar için araştırma yapma ve sonuçlarını kullanmaya yönelik tutumlarının olumlu olduğunu belirtmiştir (25). Bu kapsamda hemşirelik öğrencilerinin bilimsel çalışmalara dahil edilmesi ile araştırma farkındalıklarının artacağı mesleki gelişimlerine olumlu katkı sağlayacağı ve bakım süreçlerinde kanıt temelli uygulamalara başvuracağı öngörülmektedir.

Kanada ve ABD gibi ülkelerde mezun olan hemşirelerde kanıta dayalı uygulama yeterliliği bir standart yetkinlik olarak kabul edilmektedir. Türkiye'de hemşirelik eğitimi veren üniversitelerin çok büyük bir bölümünde henüz kanıta dayalı hemşirelik anlamında mesafe alınamamıştır. Çalışmamızda da öğrencilerden hiçbiri kanıta dayalı hemşirelikle ilgili eğitim almadıklarını belirtmiştir (13). Özellikle hemşirelik eğitiminde uluslararası standartların yakalanması ve profesyonel hemşirelerin yetiştirilmesi noktasında bu konu önem arz etmektedir.

Çalışmamızda hemşirelik öğrencilerinin \%31'i daha önce en az bir kez literatür taraması yaptığını belirtmiştir. Jacobs ve ark. (2009)'a göre kanıta dayalı uygulamaların temelinin oluşturulmasında literatür tarama yetkinliğinin kazanılması önemlidir (26). Bu bağlamda çalışmamıza katılan öğrencilerin literatür taraması konusunda yetersiz sayıda olduğu görülmektedir. Konuya ilişkin uygulamalı beceri eğitimi ile birlikte literatür tarama konusunda yeterlilik kazanacakları ve bununla birlikte kanıta dayalı hemşireliğge daha fazla yönelecekleri düşünülmektedir. Çalışmamızda literatür taramasında en çok kullanılan veri tabanının Google Akademik $(\% 79,06)$ olduğu görülmektedir. Buna benzer olarak Küçük ve ark. (2017) yapmış oldukları çalışmada da en çok kullanılan veri tabanının Google Akademik olduğu, Wahous ve ark. (2016) 'nın çalışmasında da en çok kullanılan veri tabanlarının Google Akademik ve Pubmed olduğu görülmüştür (11, 13). Bunun yanında Ross (2010) yaptığ1 çalışmada ise en çok kullanılan veri tabanının Medline olduğu görülmüştür (27). Farklılıkların literatür tarama yeterliliği ve dil problemi olduğu tahmin edilmektedir.

\section{Sonuç}

Çalışmaya katılan hemşirelik öğrencilerinin kanıta dayalı hemşireliğe yönelik tutumlarının iyi düzeyde olduğu saptanmıştır. Öğrencilerin bilimsel çalışmalara ve projelere dahil edilmesi bu konudaki farkındalık düzeylerini de arttıracağ1 öngörülmektedir. Hemşirelik eğitiminin araştırma ve kanıt temelli yapılandırılması ile öğrencilerin bu konulara olan ilgi ve alaka düzeylerinin de artacağı öngörülmektedir. Bu sonuçlar doğrultusunda;

- Hemşirelik eğitiminin yeniden yapılandırılarak kanıta dayalı hemşireliğin bağımsız bir ders halinde müfredatta yer alması - Öğrencilerin bilimsel faaliyetlerde(kongre / sempozyum) daha fazla yer almasını sağlamak ve bu konuda desteklemek - Öğrencilerin literatür tarama ve araştırma becerilerinin geliştirilmesine yönelik uygulamalı akademik beceri eğitimleri düzenlemek ve desteklemek

- Kanıta dayalı hemşirelik kurslarının düzenlenmesi ve öğrencilerin katılımlarının desteklenmesini öneri olarak sunmaktayiz.

\section{Kaynaklar}

1. Mazurek MB, Fineout-Overholt E. EvidenceBasedPractice in Nursing\& Healthcare A GuideToBestPractice Second Edition. London; WoltersKluwer; 2011. p.4-5

2. Shah, H., Chung, K. "ArchieCochraneand his visionforevidence-basedmedicine." Plasticandreconstructivesurgery 124.3 (2009): 982.

3. Kathleen RS. TheImpact of Evidence-BasedPractice in NursingandtheNextBigIdeas. The Online Journal of İssues in Nursing 2013 May;18(2).

4. CareQualityCommission (CQC) (2010). Guidanceaboutcompliance: Essential standards of qualityandsafety, https://services.cqc.org.uk/sites/default/ files/gac_-_dec_2011_update.pdf Erişim: 11.10.2018
5. NursingandMidwiferyCouncil
(NMC)
(2010).

Standardsforpreregistrationnursingeducation: Draftforconsultation, https://webcache.googleusercontent. com/search?q=cache:a5ykHQ_mzQUJ:https://www. nmc.org.uk/globalassets/sitedocuments/standards/ nmc-standards-for-pre-registration-nursing-education. $\mathrm{pdf}+\& \mathrm{~cd}=1 \& \mathrm{hl}=\mathrm{tr} \& \mathrm{ct}=\mathrm{clnk} \& \mathrm{gl}=$ tr Erişim: 11.10 .2018

6. Şenyuva, E. "Hemşirelik eğitimi ve kanıta dayalı uygulamalar.” FlorenceNightingale Hemşirelik Dergisi 24.1 
(2016): 59-65.

7. Hemşirelik Yönetmeliği, http://www.saglik.gov.tr Erişim: 12.10.2018

8. Türkiye Yükseköğretim Ulusal Yeterlilikler ÇerçevesiBologna Süreci Uygulamaları (2010). https://bologna.yok. gov.tr Erişim: 11.10.2018

9. Cruz, J. P., Colet, P. C., Alquwez, N., Alqubeilat, H., Bashtawi, M. A., Ahmed, E. A., \& Cruz, C. P. "EvidenceBasedPracticeBeliefsandImplementationamongtheNursing Bridge Program Students of a SaudiUniversity." International journal of healthsciences 10.3 2016: 405.

10. Adams S. Use of evidence-basedpractice in schoolnursing: Survey of schoolnurses at a nationalconference. TheJournal of School Nursing 2009; 25: 302-313

11. Wahoush, O, \& Banfield, L. "Information literacyduringentrytopractice: Information-seekingbehaviors in studentnursesandrecentnursegraduates." NurseEducation Today34.2 (2014): 208-213.

12. Karadaş, C., \& Özdemir, L."Hemşirelik Öğrencilerinin Araştırmaya Yönelik Farkındalık ve Tutumlarının Değerlendirilmesi." Journal of Hacettepe UniversityFaculty of Nursing 2015; 2.3: 30-39

13. Küçük, E. Ö., Çakmak, S., Kapucu, S., Meltem, K. O. Ç., \& Kahveci, R. "Hemşirelik Öğrencilerinin Kanıta Dayalı Hemşirelik Uygulamalarına İlişkin Farkındalıklarının Belirlenmesi." Journal of Hacettepe UniversityFaculty of Nursing 2017; 4.2: 1-12.

14. Ayhan Y, Kocaman G, Bektaş M. "Kanıta Dayalı Hemşireliğe Yönelik Tutum Ölçeği”"ninTürkçe’ye Uyarlanması: Geçerlik ve Güvenirlik Çalışması. Hemşirelikte Araștırma Geliştirme Dergisi 2015; 17(2-3): 21-35.

15. Küçükoğlu S, Bükecik T, Aytekin A, Çeleb A. Acil birimlerde çalışan hemşirelerin adli vakayla ilgili yaklaşımları ve kanıta dayalı uygulamaları. Türkiye Klinikleri Adli Tıp ve Adli Bilimler Dergisi, 2017; 14(1): 1-8.

16. Leach JM, Hofmeyer A, Bobridge A. The impact of research education on student nurse attitude, skill and uptake of evidence-based practice: a descriptive longitudinal survey. J Clin Nurs 2015; 25: 194-203.

17. Dikmen Y, Filiz NY, Tanrıkulu F, Yılmaz D, Kuzgun

H. Attitudes of intensive care nurses towards evidence- based nursing. International Journal of Health Sciences and Research, 2018; 8(1):138-143.

18. Merih YD, Potur DC, Esencan TY.Doğum sonu kliniklerinde çalışan ebe ve hemşireler kanıta dayalı uygulamaların neresinde? Sağlık ve Hemşirelik Yönetimi Dergisi, 2017; 1(4): 8-14

19. Durmuş M, Gerçek A, Çiftci N. Sağlık çalışanlarının problem çözme becerilerinin kanıta dayalı tutum algıları üzerindeki etkisi. Akademik Sosyal Araștırmalar Dergisi, 2017; 5(52): 648-661.

20. Yılmaz D, Düzgün F, Dikmen Y. Hemşirelerin kanıta dayalı hemşireliğe yönelik tutumlarının incelenmesi. Acıbadem Üniversitesi Sağlık Bilimleri Dergisi, 2018. DOI: 10. 31067/0.2018.91.

21. Ulaş Karaahmetoğlu, G, Kaçan Softa, H . "Hemşirelik Öğrencilerinin Kanıta Dayalı Hemşireliğe Yönelik Tutumlarının İncelenmesi”. Anadolu Hemşirelik ve Sağlık Bilimleri Dergisi. 2018: 256-263

22. Kurt AA, İzmirli ÖŞ, Fırat M, İzmirli S. Bilimsel araştırma yöntemleri dersine ilişkin bilgisayar ve öğretim teknolojileri eğitimi bölümü öğrencilerinin görüşlerinin incelenmesi. Dumlupınar Üniv Sosyal Bil Derg 2011; 30: 19-28.

23. Arslan S, Şener KD, Küçük Ö. Pediatri Kliniğinde Çalışan Hemşirelerin Kanıta Dayalı Uygulamalara İlişkin Görüşleri. Yıldırım Beyazıt Üniversitesi Sağlık Bilimleri Fakültesi Hemşirelik E-Dergisi. 2015; 3(1): 1-9

24. Mehrdad N, Joolaee S, Joulaee A, Bahrani N. Nursing faculties' knowledge andattitude on evidence-based practice. Iranian Journal of Nursing Midwifery Research, 2012; 17(7): 506-511.

25. Ryan JE. Undergraduate nursing students' attitudes and use of research and evidence-based practice-an integrative literature review. J Clin Nurs 2016; 25: 1548-56.

26. Jacobs, S. K., Rosenfeld, P., \& Haber, J. "Information literacy as thefoundationforevidence-basedpractice in graduatenursingeducation: a curriculum-integratedapproach." Journal of Professional Nursing 2003; 19 (5): 320-328.

27. Ross J. Information literacyforevidence-basedpractice in perianesthesianurses: readinessforevidence-basedpractice. JournalPerianesthNurs 2010; 25(2): 64-70. 